\title{
Differential regulation of rat testicular $5 \alpha$-reductase type 1 and 2 isoforms by testosterone and FSH
}

\author{
K Pratis, L O'Donnell, G T Ooi, P G Stanton, R I McLachlan \\ and D M Robertson
}

Prince Henry's Institute of Medical Research, PO Box 5152, Clayton, Victoria 3168, Australia

(Requests for offprints should be addressed to D M Robertson; Email: david.robertson@med.monash.edu.au)

\begin{abstract}
Testosterone is metabolised to the more potent androgen, dihydrotestosterone, by the $5 \alpha$-reductase $(5 \alpha \mathrm{R})$ enzyme. We previously showed that $5 \alpha$-reduced androgens are important for maintaining androgen action on rat spermatogenesis when testicular testosterone concentrations are reduced. This study investigated expression and activity of the $5 \alpha \mathrm{R}$ isoforms, type $1(5 \alpha \mathrm{R}-1)$ and type $2(5 \alpha \mathrm{R}-2)$, in the rat during hormone manipulation in order to understand the factors that regulate the testicular concentration of $5 \alpha \mathrm{R}$ and testicular $5 \alpha$-reduced androgen biosynthesis. Testicular $5 \alpha \mathrm{R}-1$ and $5 \alpha \mathrm{R}-2 \mathrm{mRNA}$ and enzyme activity were measured by real-time PCR and specific enzyme assays respectively. Hormone levels were first suppressed using two models of gonadotrophin suppression: testosterone and oestradiol treatment (LH/testosterone deficiency) or $\mathrm{GnRH}$ immunisation (LH/testosterone and $\mathrm{FSH}$ deficiency). Hormones were then either restored or suppressed for 6 days by a variety of hormonal treatments. $5 \alpha \mathrm{R}-1$ mRNA and enzyme activity increased when
\end{abstract}

testosterone was suppressed, yet restoration of testosterone decreased $5 \alpha \mathrm{R}-1$ mRNA and enzyme activity, suggesting that testosterone negatively regulates $5 \alpha \mathrm{R}-1$. Suppression of FSH decreased $5 \alpha \mathrm{R}-1$ mRNA yet FSH administration increased $5 \alpha \mathrm{R}-1$ mRNA, but no changes in $5 \alpha \mathrm{R}-1$ activity were observed within the 6 day period. In contrast to $5 \alpha \mathrm{R}-1$, testosterone did not affect the testicular concentration of $5 \alpha \mathrm{R}-2$ mRNA or activity, but there was evidence for modulation of $5 \alpha \mathrm{R}-2$ activity by FSH. Measurement of testicular androgens revealed that $5 \alpha \mathrm{R}-1$ was primarily responsible for the production of $5 \alpha$-reduced metabolites. It is concluded that the $5 \alpha \mathrm{R}$ isoforms in rat testis are differentially regulated by testosterone and FSH: testosterone negatively regulated $5 \alpha \mathrm{R}-1$ mRNA and enzyme activity but had no affect on $5 \alpha \mathrm{R}-2$, whereas FSH positively regulated $5 \alpha \mathrm{R}-1 \mathrm{mRNA}$ and appeared to regulate $5 \alpha \mathrm{R}-2$.

Journal of Endocrinology (2003) 176, 393-403

\section{Introduction}

Testosterone is the predominant androgen involved in the regulation of normal spermatogenesis in the rat due to its high intratesticular concentration (Wright \& Frankel 1979). The process of spermatogenesis is critically dependent on testosterone and the amount of sperm produced is dose-responsive to the level of testosterone in the testis (Awoniyi et al. 1989, McLachlan et al. 1994). The $5 \alpha$-reduction of testosterone to the more potent androgen, $5 \alpha$-dihydrotestosterone (DHT), is postulated to be important for maintaining spermatogenesis when intratesticular testosterone concentrations are low (Anderson et al. 1996, O'Donnell et al. 1996, 1999).

Testosterone has been the target for suppressing spermatogenesis in numerous contraceptive trials. In both primates (Narula et al. 2002) and men (McLachlan et al. 2002), gonadotrophin suppression by exogenous testosterone administration caused a marked reduction in testicular testosterone levels yet maintenance of $5 \alpha$-reduced androgen levels. It is thought that maintenance of testicular $5 \alpha$-reduced androgen levels may be responsible for continued low levels of sperm production in the $\sim 30 \%$ of normal men whose sperm counts do not fall to zero (azoospermia) after testosterone contraceptive treatment (Anderson et al. 1996, 1997). In the rat model of spermatogenic suppression, administration of a $5 \alpha$-reductase (5aR) inhibitor to prevent DHT production suppressed spermatogenesis (O’Donnell et al. 1996, 1999). Furthermore, administration of the androgen receptor (AR) antagonist flutamide during spermatogenic suppression in the rat increased the production of $5 \alpha$-reduced metabolites in the testis, suggesting that $5 \alpha \mathrm{R}$ may be hormonally regulated (O'Donnell et al. 1999). Taken together, these studies suggest that testicular $5 \alpha \mathrm{R}$ may be regulated by gonadotrophins and/or testosterone and that $5 \alpha \mathrm{R}$ activity is important for determining the amount of bioactive androgen in the testis. 
Two isoforms of $5 \alpha \mathrm{R}$, type $1(5 \alpha \mathrm{R}-1)$ and type 2 $(5 \alpha \mathrm{R}-2)$, have been cloned in rats and humans (Andersson \& Russell 1990, Normington \& Russell 1992). These isoforms are products of different genes and possess different biochemical properties: $5 \alpha \mathrm{R}-1$ has a micromolar affinity for steroid substrates with peak activity extending over a broad neutral $\mathrm{pH}$ range, whereas $5 \alpha \mathrm{R}-2$ has a nanomolar affinity for steroid substrates with peak activity at pH 5.0 (Andersson \& Russell 1990). The $5 \alpha \mathrm{R}$ isoforms have not been extensively investigated in rat testis. Viger \& Robaire (1995) used Northern blots to show expression of $5 \alpha \mathrm{R}-1$ in postnatal and adult rat testis, whereas $5 \alpha \mathrm{R}-2$ was not detected. In contrast, Normington \& Russell (1992) used RNA blot hybridisation to show that $5 \alpha \mathrm{R}-2$ was the predominant isoform expressed in adult rat testis. The development of enzyme activity assays for measuring rat testicular $5 \alpha \mathrm{R}-1$ and $5 \alpha \mathrm{R}-2$ activity in the presence of high $5 \alpha \mathrm{R}-1$ levels revealed that $5 \alpha \mathrm{R}-1$ was the predominant isoform in the pubertal and adult rat testis, with both $5 \alpha \mathrm{R}$ isoforms being lower in adult testis (Pratis et al. 2000).

Understanding the regulation of the testicular $5 \alpha \mathrm{R}$ isoforms is important, given their central role in androgen biosynthesis, and thus the potential for influencing sperm production. Thus, the aim of this study was to investigate the hormonal regulation of $5 \alpha \mathrm{R}-1$ and $5 \alpha \mathrm{R}-2 \mathrm{mRNA}$ and enzyme activity in adult rat testis, using two in vivo models of luteinizing hormone (LH)/testosterone and/or folliclestimulating hormone (FSH) suppression. LH/testicular testosterone was suppressed with testosterone and oestradiol implants, and $\mathrm{LH} /$ testosterone and $\mathrm{FSH}$ was suppressed by active immunisation of rats against gonadotrophin-releasing hormone $(\mathrm{GnRH})$. In both models, the AR antagonist, flutamide, was used to suppress residual levels of androgens, and residual FSH levels were suppressed with an FSH antiserum. Testosterone was partially or fully restored with high doses of testosterone (using implants) and human chorionic gonadotrophin (hCG) respectively. FSH action was restored by administering recombinant human FSH (rhFSH). The $5 \alpha \mathrm{R}-1$ and $5 \alpha \mathrm{R}-2$ mRNA levels were quantified by real-time PCR and enzyme activities were measured with an in vitro activity assay.

\section{Materials and Methods}

\section{Reagents, hormones and drugs}

Organic solvents were purchased from Sigma-Aldrich (Milwaukee, WI, USA) and thin layer chromatography plates (ITLC-SA) were obtained from Gelman Sciences (NSW, Australia). Non-radioactive steroids were purchased from Sigma (St Louis, MO, USA), radioactive steroids were purchased from Du Pont-New England Nuclear (Boston, MA, USA). $\left[4-{ }^{14} \mathrm{C}\right]-3 \alpha$-androstanediol ( $3 \alpha$-Adiol) was prepared as described previously (Pratis et al. 2000). Flutamide (Sigma) was dissolved in methylene chloride and added to peanut oil (methylene chloride:oil, $1: 2 \mathrm{v} / \mathrm{v})$. The methylene chloride was evaporated by bubbling with nitrogen and warming the solution to $37^{\circ} \mathrm{C}$. The FSH. $A b$ was an immunoglobulin fraction of anti-rat FSH antibody raised in sheep (FSH. $A b$ \#1792; Meachem et al. 1998). rhFSH (Gonal-F) was obtained from Serono (Sydney, Australia). hCG (Pregnyl) was obtained from Organon (Sydney, Australia).

\section{Animals}

Adult male Sprague-Dawley rats were obtained from the Monash Central Animal House (Clayton, Australia) and housed under a $12 \mathrm{~h}$ light: $12 \mathrm{~h}$ darkness cycle with free access to food and water. Animals were killed by $\mathrm{CO}_{2}$ asphyxiation, blood was removed by cardiac puncture and the testes quickly removed, trimmed of fat, weighed and frozen in liquid nitrogen. Blood was stored at $-20{ }^{\circ} \mathrm{C}$ and testes were stored at $-70{ }^{\circ} \mathrm{C}$ until required. These studies were approved by the Monash Medical Centre Animal Ethics Committee.

\section{Experimental design}

Two in vivo models of gonadotrophin suppression were used to investigate the regulation of $5 \alpha \mathrm{R}$ by testosterone and FSH. All animals except controls received two injections, one in oil and the other in normal rat serum (NRS). All preparations (except flutamide) were prepared in 15\% NRS and filtered through a $0 \cdot 2 \mu \mathrm{m}$ filter (Millipore, Bedford, MA, USA). Vehicle oil injections were similarly prepared except the drug/hormone was omitted.

\section{Testosterone and oestradiol suppression model} Testosterone $(3 \mathrm{~cm})$ and oestradiol $(0 \cdot 4 \mathrm{~cm})(\mathrm{TE})$ implants were prepared by filling medical-grade polydimethylsiloxane Silastic tubing (outer diameter (o.d.) $3.18 \mathrm{~mm}$; inner diameter (i.d.) $1.98 \mathrm{~mm}$; Dow-Corning, Midland, MI, USA) with testosterone and oestradiol respectively. Twenty-four centimetre testosterone (T24) implants were prepared using $3 \times 8 \mathrm{~cm}$ testosterone implants. Animals were anaesthetised by ether inhalation (as approved by Monash Medical Centre Animal Ethics Committee) before implantation and the steroid implants placed s.c. along the animals' dorsal surface. Six groups of adult rats received TE implants for 61 days (Table 1). Following TE suppression and during the treatment phase, three groups retained the TE implants while in the other three groups the TE implants were replaced with T24 implants. TE- and T24-treated animals received vehicle, flutamide $(20 \mathrm{mg} /$ $\mathrm{kg}$ per day), or FSH. $A b(2 \mathrm{mg} / \mathrm{kg}$ per day). Controls did not receive TE implants or any treatment during the treatment phase.

GnRH immunisation model Animals were actively immunised against $\mathrm{GnRH}$ with a proprietary $\mathrm{GnRH}$ 
Table 1 TE suppression model. Animals received T24 implants on day 2 of the treatment phase

\begin{tabular}{|c|c|c|c|}
\hline & $n$ & $\begin{array}{l}\text { Suppression } \\
\text { phase } \\
\text { (8 weeks) }\end{array}$ & $\begin{array}{l}\text { Treatment } \\
\text { phase } \\
(6 \text { days })\end{array}$ \\
\hline \multicolumn{4}{|l|}{ Group } \\
\hline 1 & 8 & - & Untreated control \\
\hline 2 & 8 & TE & $\mathrm{TE}+$ vehicle \\
\hline 3 & 8 & TE & $\mathrm{TE}+$ flutamide \\
\hline 4 & 7 & TE & $\mathrm{TE}+\mathrm{FSH} . A b$ \\
\hline 5 & 8 & TE & T24+vehicle \\
\hline 6 & 8 & TE & T24+flutamide \\
\hline 7 & 8 & TE & $\mathrm{T} 24+\mathrm{FSH} . A b$ \\
\hline
\end{tabular}

immunogen preparation (BA-1666-4; Biotech, Roseville, NSW, Australia) incorporating an adjuvant free of myobacterial components (Stewart et al. 1992). Animals received $100 \mu \mathrm{l} \mathrm{GnRH}$ immunogen every 4 weeks at a single s.c. site over a 12 -week period as previously described (McLachlan et al. 1994, 1995, Meachem et al. 1998). Five groups of adult rats received GnRH immunisations (Table 2). During the treatment phase animals received either vehicle, FSH. $A b$ ( $2 \mathrm{mg} / \mathrm{kg}$ per day), or rhFSH (25 IU/kg per day), and two GnRH-immunised groups were treated with hCG $(2 \cdot 5 \mathrm{IU} / \mathrm{kg}$ per day). Controls did not receive the immunogen or any treatment during the treatment phase.

\section{$5 a R m R N A$}

Total RNA was extracted from rat testis using the Qiagen RNeasy kit (Qiagen, VIC, Australia) and treated with DNAse (DNA-free; Ambion, Austin, TX, USA) to remove any contaminating DNAs. Extracted RNA $(2 \mu \mathrm{g})$ was reverse transcribed with either $100 \mathrm{ng}$ random primer (for $5 \alpha \mathrm{R}-1$ mRNA) or $125 \mathrm{ng}$ oligo $(\mathrm{dT})_{12-18}$ (for $5 \alpha \mathrm{R}-2$ mRNA) at $42{ }^{\circ} \mathrm{C}$ for $50 \mathrm{~min}$ using $50 \mathrm{U}$ of Expand reverse transcriptase (Roche Molecular, Mannheim, Germany). Following reverse transcription, the reaction was terminated by heating at $70{ }^{\circ} \mathrm{C}$ for $15 \mathrm{~min}$. The cDNAs were stored at $4{ }^{\circ} \mathrm{C}$ until required for use in real-time PCR.

$5 \alpha \mathrm{R}$ mRNA was quantified by real-time RT-PCR amplification in a LightCycler (Roche) instrument (Bustin

Table 2 GnRH immunisation $\left(\mathrm{GnRH}_{\text {imm }}\right)$ model

\begin{tabular}{|c|c|c|c|}
\hline & $n$ & $\begin{array}{l}\text { Suppression } \\
\text { phase } \\
\text { (12 weeks) }\end{array}$ & $\begin{array}{l}\text { Treatment } \\
\text { phase } \\
(6 \text { days })\end{array}$ \\
\hline \multicolumn{4}{|l|}{ Group } \\
\hline 1 & 8 & - & Untreated control \\
\hline 2 & 8 & $\mathrm{GnRH}_{i m m}$ & $\mathrm{GnRH}_{i m m}+$ vehicle \\
\hline 3 & 8 & $\mathrm{GnRH}_{i m m}$ & $\mathrm{GnRH}_{i m m}+\mathrm{FSH} . A b$ \\
\hline 4 & 8 & $\mathrm{GnRH}_{i m m}$ & $\mathrm{GnRH}_{i m m}+\mathrm{rhFSH}$ \\
\hline 5 & 8 & $\mathrm{GnRH}_{i m m}$ & $\mathrm{GnRH}_{i m m}+\mathrm{hCG}$ \\
\hline 6 & 8 & $\mathrm{GnRH}_{i m m}$ & $\mathrm{GnRH}_{i m m}+\mathrm{hCG}+\mathrm{FSH} . A b$ \\
\hline
\end{tabular}

2000) using SYBR Green I fluorescence detection of amplified products. The forward $\left(5^{\prime}-\mathrm{TCC}\right.$ TGG TCA CCT TTG TCT TGG C-3') and reverse (5'-GTT TCC CCT GGT TTT CTC AGA TTC-3') primers for $5 \alpha \mathrm{R}-1$ were designed to produce a $128 \mathrm{bp}$ amplicon. The forward (5'-ACA TCC ACA GTG ACT ACA CCC TGC-3') and reverse $\left(5^{\prime}-\mathrm{TCC}\right.$ ATT CAA TAA TCT CGC CCA G-3') primers for $5 \alpha \mathrm{R}-2$ were designed to produce a $207 \mathrm{bp}$ amplicon. A $20 \mu \mathrm{l}$ PCR reaction was used and included PCR grade water $(10.8 \mu \mathrm{l}), 5 \mathrm{mmol} / \mathrm{l} \mathrm{mag}-$ nesium chloride, specific reverse and forward primers $(0.5 \mu \mathrm{mol} / 1$ final concentration for $5 \alpha \mathrm{R}-1$ and $0.375 \mu \mathrm{mol} / 1$ final concentration for $5 \alpha \mathrm{R}-2)$, SYBR Green dye $(2 \mu \mathrm{l})$ and reverse-transcribed cDNAs $(2 \mu \mathrm{l}$, diluted 1:10). An initial denaturation step of $10 \mathrm{~min}$ was used for both $5 \alpha \mathrm{R}-1$ and $5 \alpha \mathrm{R}-2$. PCR amplification for $5 \alpha \mathrm{R}-1$ consisted of 38 cycles at $95{ }^{\circ} \mathrm{C}$ for $15 \mathrm{~s}$ (denaturation), $55^{\circ} \mathrm{C}$ for $5 \mathrm{~s}$ (annealing), and $72{ }^{\circ} \mathrm{C}$ for $10 \mathrm{~s}$ (elongation). PCR amplification for $5 \alpha \mathrm{R}-2$ consisted of 40 cycles at $95{ }^{\circ} \mathrm{C}$ for $15 \mathrm{~s}$ (denaturation), $62{ }^{\circ} \mathrm{C}$ for $5 \mathrm{~s}$ (annealing), and $72{ }^{\circ} \mathrm{C}$ for $10 \mathrm{~s}$ (elongation). The DNA standards were highly purified and sequence-verified cDNAs, which were identical to the real-time PCR products to ensure equal amplification efficiency between standards and PCR products. For each quantification, standard curves consisting of twofold dilutions of the appropriate $5 \alpha \mathrm{R}$ cDNA were included, and these ranged between 1 and $0 \cdot 0625 \mathrm{fg}$ for $5 \alpha \mathrm{R}-1$ and $0 \cdot 2$ and $0.0125 \mathrm{fg}$ for $5 \alpha \mathrm{R}-2$. Following PCR, melting curve analysis was performed on the amplified product to ensure that only specific PCR amplicons were obtained and quantified. This was also confirmed by nucleotide sequencing. The mRNA data obtained from the LightCycler were normalised against $28 \mathrm{~S}$ ribosomal RNA, which was quantified by electrophoresing equivalent RNA on an agarose gel and the 28S ribosomal RNA fluorescence measured using a CCD camera with Quantity One 5.1 software (Bio-Rad, NSW, Australia). All measurements were done within the linear range under non-saturating pixel conditions. The electrophoresed RNA was also used to confirm the integrity of all RNAs used in the real-time PCR analysis. All samples were measured in eight separate assays. Between-assay variation as determined from the reproducibility of a quality control sample was $8 \cdot 9 \%$ for $5 \alpha \mathrm{R}-1$ and $8 \cdot 8 \%$ for $5 \alpha \mathrm{R}-2.5 \alpha \mathrm{R}-1$ and $5 \alpha \mathrm{R}-2$ mRNA was measured in all animals except for the T24-treated animals in the TE suppression study due to insufficient sample amounts.

\section{5aR enzyme activity}

The remainder of the left testis was homogenised in $0.25 \mathrm{~mol} / 1$ sucrose, centrifuged at $10000 \mathrm{~g}$ for $20 \mathrm{~min}$ and the supernatant used for measuring $5 \alpha \mathrm{R}-1$ and $5 \alpha \mathrm{R}-2$ enzyme activity with enzyme assays validated previously (Pratis et al. 2000). 5 $\alpha \mathrm{R}-1$ activity was measured at $\mathrm{pH} 7 \cdot 0$ 
and $5 \alpha \mathrm{R}-2$ activity was determined at $\mathrm{pH} 5 \cdot 0$. The contribution of the $5 \alpha \mathrm{R}-1$ isoform at $\mathrm{pH} 5 \cdot 0$ in the $5 \alpha \mathrm{R}-2$ activity measured (i.e. overlap) was determined and subtracted to give specific $5 \alpha \mathrm{R}-2$ enzyme activity.

Briefly, the two assays measure the conversion of $\left[{ }^{3} \mathrm{H}\right]$ testosterone to ${ }^{3} \mathrm{H}[\mathrm{DHT}]+\left[{ }^{3} \mathrm{H}\right] 3 \alpha$-Adiol in $0 \cdot 1 \mathrm{~mol} / 1$ Tris-citrate buffer at their respective $\mathrm{pH}$, followed by steroid extraction with toluene:ether (1:5), steroid separation with TLC, and steroid quantification by scintillation $\beta$-counting. $5 \alpha \mathrm{R}$ activity was expressed as the amount of DHT and 3 $\alpha$-Adiol produced after corrections for procedural losses, determined using $\left[{ }^{14} \mathrm{C}\right]$ steroids (testosterone, DHT and 3 $\alpha$-Adiol) as internal standards. The blank activity for the $5 \alpha \mathrm{R}$ assay (in the absence of testicular supernatant) was $0 \cdot 010 \pm 0 \cdot 003 \mathrm{pmol} \mathrm{DHT}+3 \alpha$-Adiol/ min $(n=6)$, which corresponded to less than $0 \cdot 12 \%$ conversion of substrate.

\section{LH, FSH and testicular steroids}

Serum LH was measured by immunofluorometric assay (Haavisto et al. 1993) using rat LH (rLHRP-3; NIDDK, Bethesda, MD, USA) as a standard. All samples were assayed in two assays with a detection limit of $0.02 \mathrm{ng} / \mathrm{ml}$. Serum FSH was measured by RIA using iodinated rat FSH (rFSH 17; NIDDK) as tracer, rFSH antiserum (anti-rFSH S11; NIDDK), and rFSH RP2 as standard. All samples were assayed in two assays with a detection limit of $1.5 \mathrm{ng} / \mathrm{ml}$.

The right testis from each rat was kept for measurement of testicular steroids. Testicular testosterone, DHT and $3 \alpha$-Adiol were extracted with acetonitrile, separated by HPLC and measured by RIA, as described previously (O'Donnell et al. 1996). The within-assay variations for testosterone, DHT and 3 $\alpha$-Adiol were 8, 13 and $12 \%$ respectively, and the between-assay variations were 8,3 and $8 \%$ respectively ( $n=6$ assays).

\section{Statistics}

Differences between groups (data with equal variances, as assessed by Bartlett's test) were assessed by ANOVA and independent $t$-tests. Data with unequal variances were assessed by the Kruskal-Wallis test and Dunn's multiple comparison test between selected treatment groups. All data were expressed as means \pm S.E.M. $(n=7$ or 8$)$ and considered significant when $P<0 \cdot 05$ was achieved.

\section{Results}

\section{TE suppression model}

Serum LH and FSH Serum LH was suppressed $(P<0 \cdot 05)$ in all TE-treated groups compared with controls and administration of flutamide to TE- and T24-treated groups increased $(P<0 \cdot 05)$ LH levels above corresponding
Table 3 TE suppression model: serum LH and FSH, means \pm S.E.M. (see Table 1 and Methods section for further details)

\begin{tabular}{|c|c|c|}
\hline & LH (ng/ml) & FSH (ng/ml) \\
\hline \multicolumn{3}{|l|}{ Treatment group } \\
\hline Untreated control & $1 \cdot 15 \pm 0 \cdot 15$ & $3 \cdot 65 \pm 0 \cdot 12$ \\
\hline TE+vehicle & $0 \cdot 12 \pm 0.02^{*}$ & $3 \cdot 06 \pm 0 \cdot 11$ \\
\hline $\mathrm{TE}+$ flutamide & $0 \cdot 69 \pm 0 \cdot 16^{\star \dagger}$ & $6 \cdot 47 \pm 0 \cdot 84^{* \dagger}$ \\
\hline $\mathrm{TE}+\mathrm{FSH} . A b$ & $0 \cdot 08 \pm 0.01^{*}$ & NA \\
\hline T24+vehicle & $0 \cdot 11 \pm 0.02^{*}$ & $4 \cdot 02 \pm 0 \cdot 33$ \\
\hline T24+flutamide & $0.41 \pm 0.09^{* \dagger}$ & $5 \cdot 59 \pm 0.52$ \\
\hline $\mathrm{T} 24+\mathrm{FSH} . A b$ & $0 \cdot 08 \pm 0.01^{*}$ & $\mathrm{NA}$ \\
\hline
\end{tabular}

NA denotes not assayed due to interference of FSH.Ab in the FSH RIA. ${ }^{*}$ Significant difference compared with untreated control. ${ }^{\dagger}$ Significant difference compared with corresponding TE+vehicle or T24+vehicle.

vehicle-treated animals (Table 3). Serum FSH was not affected by TE or T24 treatment; however, TE+flutamide treatment significantly increased FSH above TE+vehicle (Table 3).

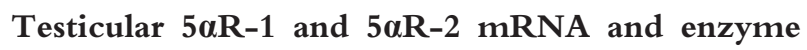
activity There was no difference in the housekeeping gene $28 \mathrm{~S}$ ribosomal RNA between any of the treatment groups (Fig. 1A). 5 $\alpha$ R-1 mRNA (Fig. 1B) and enzyme activity (Fig. 1C) in TE-suppressed animals increased $(P<0 \cdot 05)$ above controls levels, while administration of flutamide to TE-suppressed rats further increased $5 \alpha \mathrm{R}-1$ mRNA and enzyme activity levels $(P<0 \cdot 05$, Fig. 1B and C). T24 treatment did not change $5 \alpha \mathrm{R}-1$ enzyme activity compared with $\mathrm{TE}+$ vehicle treatment; however, T24+flutamide treatment increased $(P<0 \cdot 05) \quad 5 \alpha \mathrm{R}-1$ enzyme activity above the T24+vehicle group (Fig. 1C). TE + FSH. $A b$ treatment decreased $(P<0 \cdot 05) \quad 5 \alpha \mathrm{R}-1$ mRNA compared with TE+vehicle treatment but did not change $5 \alpha \mathrm{R}-1$ enzyme activity.

$5 \alpha \mathrm{R}-2$ mRNA was suppressed below control by TE suppression $(P<0 \cdot 05)$, while acute FSH. $A b$ treatment further suppressed $5 \alpha \mathrm{R}-2 \mathrm{mRNA}$ levels by $\sim 4.5$-fold $(P<0 \cdot 05$, Fig. 1D). 5 $\alpha$ R-2 enzyme activity was not affected by these treatments (Fig. 1E).

Testicular steroids TE treatment suppressed testicular testosterone to $<3 \%$ of control levels $(P<0 \cdot 05$, Fig. $2 \mathrm{~A}$ ), whereas DHT and $3 \alpha$-Adiol (Fig. $2 \mathrm{~B}$ and $\mathrm{C}$ respectively) were suppressed to 26 and $53 \%$ of controls $(P<0 \cdot 05)$ respectively. Flutamide administration significantly increased DHT and 3 $\alpha$-Adiol levels compared with TE treatment, in the absence of a significant increase in testosterone. Acute FSH. $A b$ administration did not significantly alter any of the androgens. TE suppression significantly increased the conversion of testosterone to $5 \alpha$-reduced metabolites (DHT $+3 \alpha$-Adiol/testosterone, Fig. 2D). Co-administration of flutamide significantly $(P<0 \cdot 05)$ increased this conversion while FSH had no effect. 


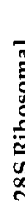
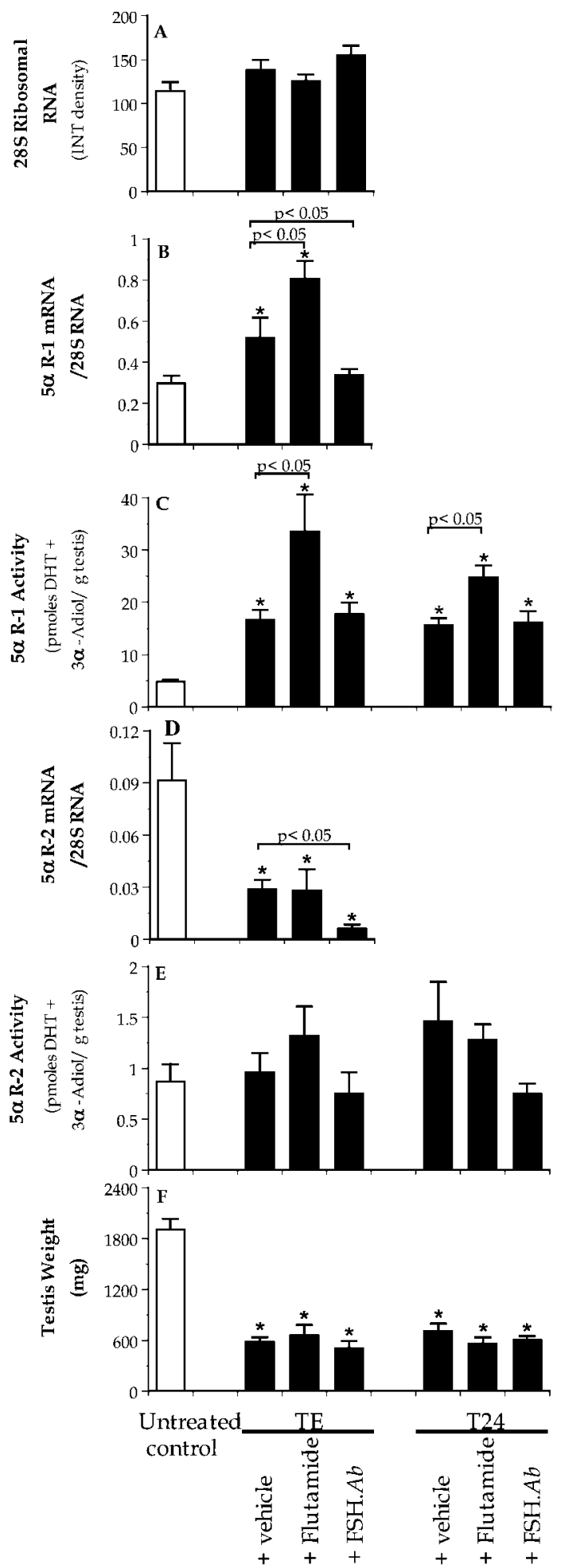

www.endocrinology.org
GnRH immunisation model

Serum LH and FSH GnRH immunisation significantly suppressed both serum $\mathrm{LH}$ and $\mathrm{FSH}$ below control levels and administration of hCG to GnRH-immunised animals partially restored $(P<0 \cdot 05)$ serum FSH (Table 4$)$. Administration of hCG to GnRH-immunised animals partially restored serum $\mathrm{FSH}$, presumably as a consequence of a rise in circulating testosterone, which stimulates FSH in a GnRH-independent manner (Rea et al. 1986, Bhasin et al. 1987).

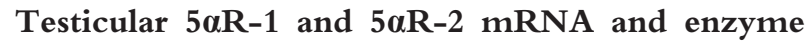
activity There was no difference in the housekeeping gene $28 \mathrm{~S}$ ribosomal RNA between any of the treatment groups (Fig 3A). 5 $\alpha$ R-1 mRNA levels (Fig. 3B) decreased to $49 \%$ of control following GnRH immunisation $(P<0 \cdot 05)$, which returned to control levels following treatment with rhFSH or hCG $(P<0 \cdot 05)$. The hCGinduced increase in $5 \alpha \mathrm{R}-1$ mRNA was inhibited $(P<0 \cdot 05)$ by the co-administration of FSH.Ab. $5 \alpha \mathrm{R}-1$ enzyme activity (Fig. 3C) was significantly increased above control by GnRH immunisation, and this increase was not affected by administration of FSH. $A b$ or rhFSH. However, hCG treatment, with or without FSH.Ab treatment, suppressed $(P<0 \cdot 05) 5 \alpha \mathrm{R}-1$ enzyme activity below the corresponding GnRH immunisation+vehicle treatment.

$5 \alpha$ R-2 mRNA (Fig. 3D) appeared to be lower in GnRH-immunised animals; however, this was not significant. Co-administration of FSH. $A b$ with hCG treatment increased $5 \alpha \mathrm{R}-2$ mRNA compared with corresponding vehicle-treated animals $(P<0 \cdot 05) .5 \alpha \mathrm{R}-2$ enzyme activity (Fig. 3E) was suppressed $(P<0 \cdot 05)$ by GnRH immunisation and restored to control levels with rhFSH or hCG treatment $(P<0 \cdot 05)$. The hCG-induced increase in $5 \alpha \mathrm{R}-2$ enzyme activity was prevented by co-administration of FSH. $A b(P<0 \cdot 05)$.

Testicular steroids GnRH immunisation suppressed testicular testosterone to $<2 \%$ of control $(P<0 \cdot 05$, Fig. 4A). hCG treatment (with or without FSH. $A b$ ) significantly increased testosterone levels. Testicular DHT (Fig. 4B) and 3 $\alpha$-Adiol (Fig. 4C) in GnRH-immunised animals did not change with rhFSH or FSH. $A b$ treatment.

$\mathrm{GnRH}$ immunisation increased the conversion of testosterone to $5 \alpha$-reduced metabolites (DHT $+3 \alpha$-Adiol/

Figure $15 \alpha$ R-1 and 5 $\alpha$ R-2 mRNA (B and D respectively) and enzyme activity ( $C$ and $E$ respectively) in the TE model. Untreated controls are represented by the open bars and TE and T24-treated rats administered with vehicle, flutamide or FSH.Ab are represented by the closed bars. The housekeeping gene (A; INT, intensity of band) and testis weight (F) are also represented. * Significant difference $(P<0 \cdot 05)$ compared with untreated control. Differences between treatment groups are represented at $P<0.05$. Data are expressed as means \pm S.E.M. ( $n=7$ or 8$)$. 

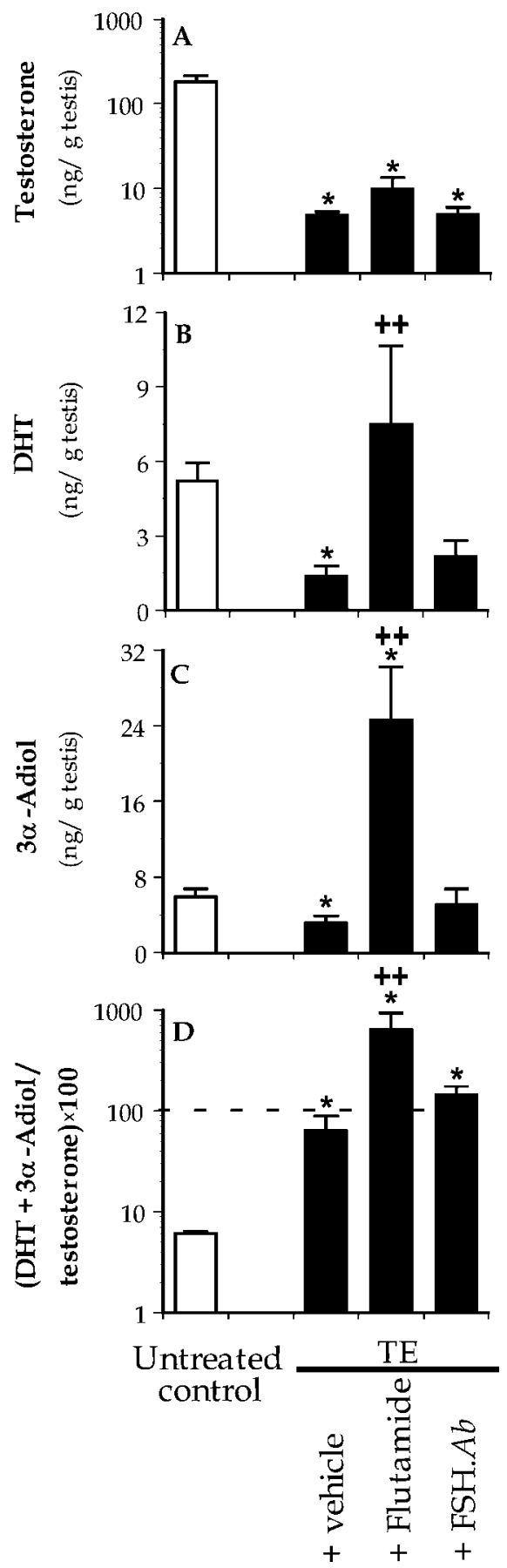

Figure 2 Testicular androgens in the TE model. Testicular concentration of testosterone ( $\mathrm{A}$; note log scale on $y$ axis), DHT (B) and $3 \alpha$-Adiol (C) in untreated control and TE-suppressed animals. Formation of $5 \alpha$-reduced androgens as a percentage of testosterone $($ (DHT 3 $\alpha$-Adiol/testosterone $) \times 100)$ represented in (D). *Significant difference $(P<0 \cdot 05)$ compared with untreated control. ${ }^{++}$Significant difference $(P<0 \cdot 05)$ compared with TE vehicle. Data expressed as means \pm S.E.M. $(n=7$ or 8$)$. Note log scale on $y$ axis in $(A)$ and $(D)$.
Table $4 \mathrm{GnRH}$ immunisation $\left(\mathrm{GnRH}_{\text {imm }}\right)$ model: serum $\mathrm{LH}$ and FSH, means \pm S.E.M. (see Table 2 and Methods section for further details)

\begin{tabular}{|c|c|c|}
\hline & LH $(\mathrm{ng} / \mathrm{ml})$ & FSH (ng/ml) \\
\hline \multicolumn{3}{|l|}{ Treatment group } \\
\hline Untreated control & $0 \cdot 74 \pm 0 \cdot 19$ & $3 \cdot 92 \pm 0 \cdot 23$ \\
\hline $\mathrm{GnRH}_{i m m}+$ vehicle & $0.09 \pm 0.01^{*}$ & $2 \cdot 1 \pm 0 \cdot 08^{*}$ \\
\hline $\mathrm{GnRH}_{i m m}+\mathrm{FSH} . A b$ & $0.05 \pm 0.01^{* \dagger}$ & NA \\
\hline $\mathrm{GnRH}_{i m m}+\mathrm{rhFSH}$ & $0 \cdot 11 \pm 0 \cdot 01^{*}$ & NA \\
\hline $\mathrm{GnRH}_{\text {imm }}+\mathrm{hCG}+$ vehicle & $0.06 \pm 0.01^{*}$ & $2 \cdot 95 \pm 0 \cdot 08^{* \dagger}$ \\
\hline $\mathrm{GnRH}_{i m m}+\mathrm{hCG}+\mathrm{FSH} . A b$ & $0 \cdot 06 \pm 0.01^{*}$ & NA \\
\hline
\end{tabular}

NA denotes not assayed due to interference of FSH.Ab or rhFSH in the FSH RIA. *Significant difference compared with untreated control.

${ }^{\dagger}$ Significant difference compared with $\mathrm{GnRH}_{i m m}+$ vehicle.

testosterone) and this increase was not affected by FSH. $A b$ or rhFSH treatment (Fig. 4D). Administration of hCG to GnRH-immunised animals decreased the conversion of testosterone to $5 \alpha$-reduced metabolites compared with GnRH-immunised+vehicle-treated animals.

\section{Discussion}

This study aimed to investigate the effects of testosterone and FSH on $5 \alpha \mathrm{R}-1$ and $5 \alpha \mathrm{R}-2$ mRNA and enzyme activity in adult rat testis in order to understand the hormonal regulation of the testicular $5 \alpha \mathrm{R}$ isoforms and their relative importance in maintaining spermatogenesis. Two in vivo models of spermatogenic suppression were used: TE implants selectively suppressed LH/testosterone but not FSH, whereas GnRH immunisation suppressed both testosterone and FSH. This study showed that the testicular $5 \alpha \mathrm{R}$ isoforms are differentially regulated by FSH and testosterone at the level of gene expression, and provides a better understanding of the control of testicular androgen biosynthesis.

\section{Effect of testosterone on $5 \alpha R-1$ and $5 \alpha R-2$}

When the TE suppression model was used to suppress testicular testosterone, $5 \alpha \mathrm{R}-1 \mathrm{mRNA}$ and enzyme activity increased, and this stimulatory effect was enhanced further by blocking residual androgen levels with the AR antagonist, flutamide. These data suggest that testosterone negatively regulates the expression of the $5 \alpha \mathrm{R}-1$ isoform. In support, restoration of testosterone by administration of hCG in combination with FSH. $A b$ (which neutralised the hCG-induced concomitant increase in FSH in this species) to GnRH-immunised animals decreased $5 \alpha \mathrm{R}-1$ mRNA and enzyme activity. Partial restoration of testosterone with T24 treatment, however, did not suppress $5 \alpha \mathrm{R}-1$ as did hCG, presumably because the concentration of testosterone was not increased sufficiently to inhibit $5 \alpha \mathrm{R}-1$. Evidence in support of this is seen from testicular steroid levels in these model systems. The amount of testosterone 

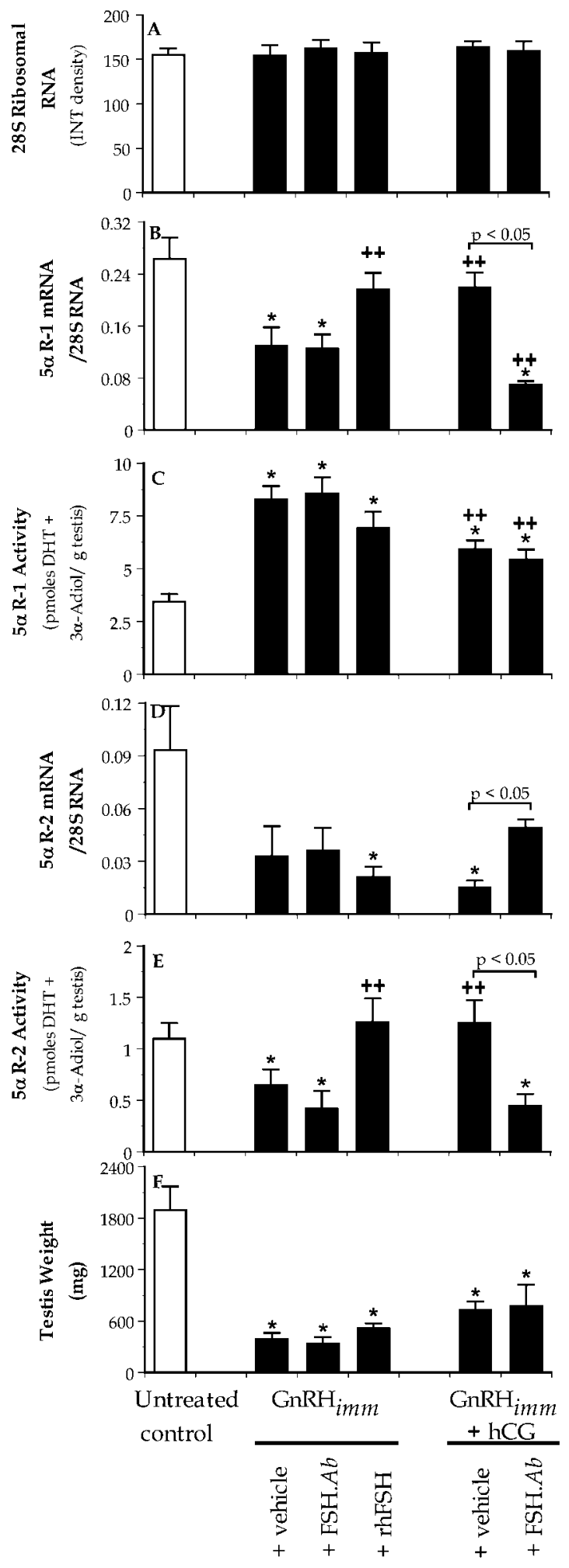

www.endocrinology.org in a normal adult rat was $\sim 100 \mathrm{ng} / \mathrm{g}$ testis and this was suppressed to $\sim 2 \mathrm{ng} / \mathrm{g}$ testis with $\mathrm{GnRH}$ immunisation. Whereas hCG treatment fully restored testosterone ( $\sim 300 \mathrm{ng} / \mathrm{g}$ testis), T24 treatment only partially restored testicular testosterone $(\sim 12 \mathrm{ng} / \mathrm{g}$ testis; O'Donnell et al. 1999). Thus the suppression of $5 \alpha \mathrm{R}-1$ mRNA and activity by testicular testosterone presumably requires levels greater than $12 \mathrm{ng} / \mathrm{g}$ testis.

Negative regulation of $5 \alpha \mathrm{R}-1$ isoform by testosterone is consistent with our hypothesis that a reduction in testicular testosterone leads to an increase in the metabolism of testosterone to the more potent metabolite, DHT. Thus, when testicular testosterone levels are low and unable to maintain sperm production, amplification of the androgenic stimulus via conversion of testosterone to DHT would enable continued low levels of spermatogenesis. Negative regulation of $5 \alpha \mathrm{R}-1$ by testosterone has been demonstrated in a number of tissues, such as liver (Yates et al. 1958, Lopez-Solache et al. 1996) and adrenal cortex (Lephart et al. 1991). Unlike the 5 $\alpha \mathrm{R}-1$ isoform, which was shown to be regulated by testosterone, the $5 \alpha \mathrm{R}-2$ isoform in rat testis was not regulated by testosterone. Thus, neither suppression nor restoration of testosterone affected $5 \alpha \mathrm{R}-2$ mRNA or enzyme activity. This is in contrast to the ventral prostate where $5 \alpha \mathrm{R}-2$ is positively regulated by androgens (Andersson \& Russell 1990). The reason for the differential regulation of the $5 \alpha \mathrm{R}$ isoforms in different tissues is unknown, but suggests that factors that regulate the $5 \alpha \mathrm{R}$ isoforms may be tissue-specific.

\section{Effect of FSH on $5 a R-1$ and $5 a R-2$}

Studies in the literature that have investigated the regulation of $5 \alpha \mathrm{R}-1$ are controversial, and have measured only enzyme activity in immature rat testis. Some studies showed an effect of FSH on 5 $5 \mathrm{R}-1$ enzyme activity (Nayfey et al. 1975, Welsh \& Wiebe 1976) whereas others did not (Dorrington \& Fritz 1975, Murono \& Payne 1979). The present study showed that acute (6 day) FSH suppression, by administering FSH. $A b$ to TE-treated rats, decreased $5 \alpha \mathrm{R}-1$ mRNA, and that FSH restoration, by rhFSH or hCG treatment to GnRH-immunised animals, increased $5 \alpha \mathrm{R}-1 \mathrm{mRNA}$. These findings demonstrate that FSH positively regulates the $5 \alpha \mathrm{R}-1$ isoform in rat testis at the mRNA level.

Figure $35 \alpha \mathrm{R}-1$ and $5 \alpha \mathrm{R}-2 \mathrm{mRNA}$ (B and D respectively) and enzyme activity ( $C$ and $E$ respectively) in the $\mathrm{GnRH}$ immunisation model. Untreated control animals are represented by the open bars and GnRH-immunised $\left(\mathrm{GnRH}_{i m m}\right)$ and $\mathrm{GnRH}_{i m m}+$ hCG-treated rats administered vehicle, $\mathrm{FSH} . \mathrm{Ab}$ or $\mathrm{rhFSH}$ are represented by closed bars. The housekeeping gene $(A)$ and testis weight $(F)$ are also represented. *Significant difference $(P<0 \cdot 05)$ compared with untreated control. ${ }^{++}$Significant difference $(P<0 \cdot 05)$ compared with $\mathrm{GnRH}_{i m m}+$ vehicle. Significant differences between treatment groups represented at $P<0 \cdot 05$. Data are expressed as means \pm S.E.M. $(n=8)$. 

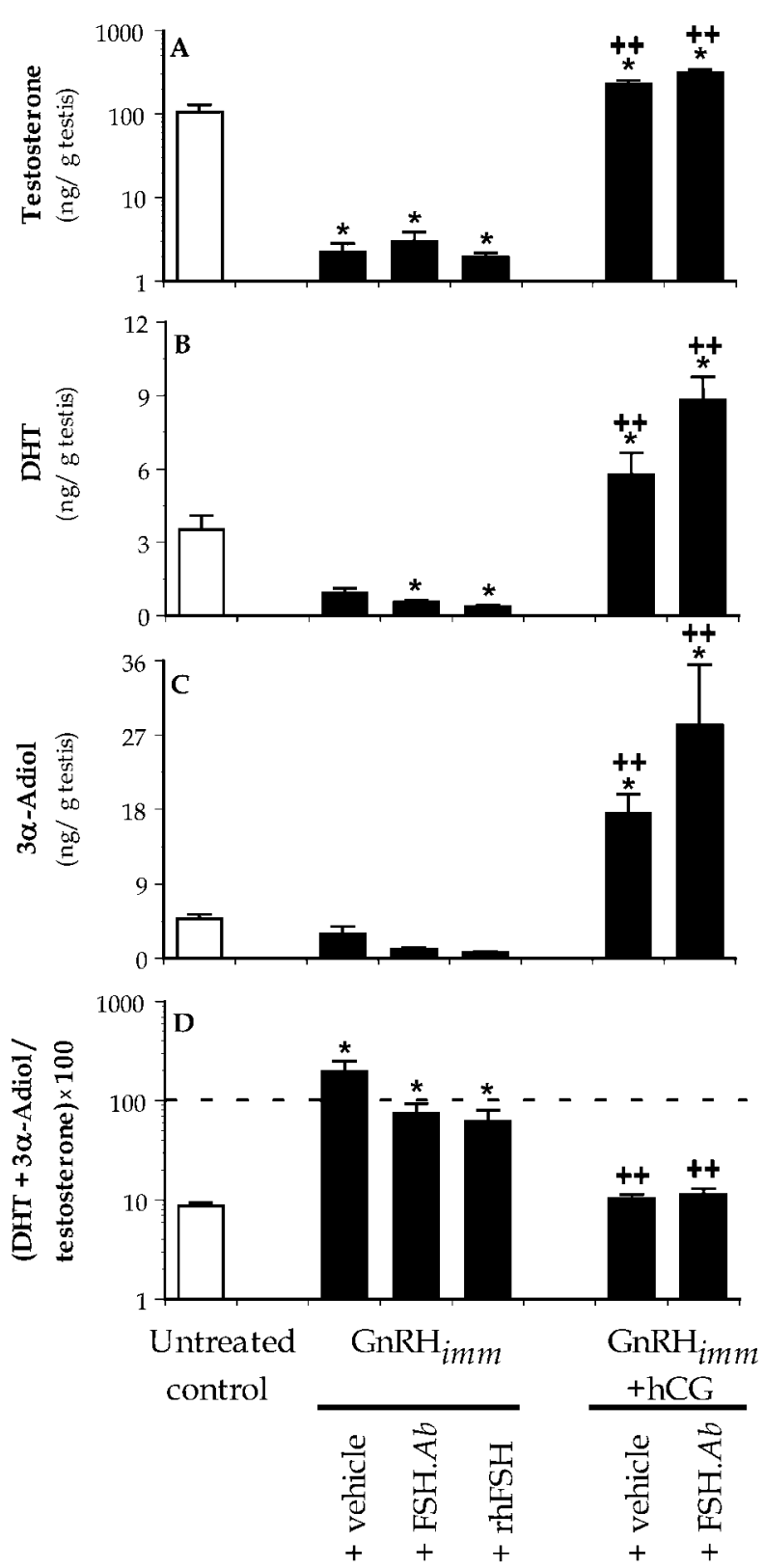

Figure 4 Testicular androgen concentrations in the GnRH immunisation model. Testicular concentration of testosterone (A; note log scale on y axis), DHT (B) and $3 \alpha$-Adiol (C) in control and $\mathrm{GnRH}$-immunised $\left(\mathrm{GnRH}_{\text {imm }}\right)$ animals. Formation of $5 \alpha$-reduced

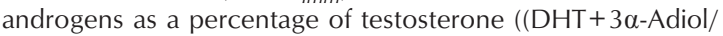
testosterone) $\times 100$ ) represented in $(\mathrm{D})$. ${ }^{*}$ Significant difference $(P<0 \cdot 05)$ compared with untreated control. ${ }^{++}$Significant difference $(P<0 \cdot 05)$ compared with $\mathrm{GnRH}_{i m m}+$ vehicle. Data are expressed as means \pm S.E.M. $(n=8)$.

Whereas FSH positively regulated $5 \alpha \mathrm{R}-1$ mRNA, neither suppression nor restoration of FSH changed $5 \alpha \mathrm{R}-1$ enzyme activity, suggesting that the regulation of the
$5 \alpha \mathrm{R}-1$ isoform by $\mathrm{FSH}$ in these studies occurred at the gene expression level and did not affect the translation of $5 \alpha \mathrm{R}-1$ mRNA into protein within the time-frame studied here. There are numerous reports in the literature that demonstrate that the level or change in $5 \alpha \mathrm{R}-1$ mRNA does not necessarily follow $5 \alpha \mathrm{R}-1$ protein levels. For example, in humans $5 \alpha \mathrm{R}-1$ mRNA expression is clearly detectable whereas there are undetected levels of $5 \alpha \mathrm{R}-1$ protein (Jenkins et al. 1992, Thigpen et al. 1993b). Viger \& Robaire (1995) showed that in the rat, $5 \alpha \mathrm{R}-1$ mRNA levels at day 90 was about one-third of that of day 30 , whereas $5 \alpha \mathrm{R}-1$ enzyme activity at day 90 was 30-fold less than that at day 30 (Rivarola et al. 1972, Pratis et al. 2000). Thus, there appears to be posttranscriptional or translational modification of the $5 \alpha \mathrm{R}-1$ isoform. In rat testis, the $5 \alpha \mathrm{R}-1$ transcript has been demonstrated to change in size with age, such that a $2 \cdot 5 \mathrm{~kb}$ $5 \alpha \mathrm{R}-1$ transcript is expressed during immaturity when $5 \alpha \mathrm{R}-1$ activity is high, and a $2.7 \mathrm{~kb}$ transcript is expressed in the adult, which coincides with the period when $5 \alpha \mathrm{R}-1$ activity levels are low, suggesting that $5 \alpha \mathrm{R}-1$ enzyme activity may depend on the transcript size of the $5 \alpha \mathrm{R}-1$ mRNA (Viger \& Robaire 1995).

There are several studies showing discordant patterns of mRNA and protein expression. For example, DHT decreased AR mRNA but increased AR protein in LnCaP and MDA453 cell lines (Yeap et al. 1999) and in rat prostatic smooth muscle cells, androgen withdrawal increased steroid sensitive gene 1 (SSG1) mRNA whereas SSG1 protein decreased (Marcantonio et al. 2001). The discordant response between mRNA and activity for this study (described above) could relate to differences in the half-life of the mRNA and protein. The half-life of recombinant $5 \alpha \mathrm{R}-1$ protein is $\sim 30 \mathrm{~h}$ (Thigpen et al. 1993a) whereas the half-life of $5 \alpha \mathrm{R}-1$ mRNA is unknown. A short half-life would indicate that mRNA and enzyme activity levels would be critically dependent on the time-point at which measurements were taken, suggesting that further studies are required to determine the changes in $5 \alpha \mathrm{R}-1$ mRNA and activity at different time-points following treatment.

$5 \alpha \mathrm{R}-2$ enzyme activity was suppressed by $\mathrm{GnRH}$ immunisation, and restoration of FSH by rhFSH or hCG treatment following GnRH immunisation, increased $5 \alpha \mathrm{R}-2$ enzyme activity to control levels. These findings suggest that FSH positively regulates $5 \alpha \mathrm{R}-2$ enzyme activity. In support, blocking the concomitant rise in FSH that occurs with hCG treatment prevented the restoration of $5 \alpha \mathrm{R}-2$ activity, providing further evidence that FSH positively regulates $5 \alpha \mathrm{R}-2$ enzyme activity. Whereas FSH affected 5 $\alpha$ R-2 enzyme activity, FSH did not change the levels of $5 \alpha \mathrm{R}-2$ mRNA. The FSH-induced increase in $5 \alpha \mathrm{R}-2$ enzyme activity but not mRNA could be due to the time-point at which samples were collected after treatment, as described above for $5 \alpha \mathrm{R}-1$. It is conceivable that FSH caused an initial increase in mRNA within 
1-2 days of treatment, which then declined to control levels. The half-life of recombinant $5 \alpha \mathrm{R}-2$ protein is similar to that of recombinant $5 \alpha \mathrm{R}-1(\sim 30 \mathrm{~h}$; Thigpen et al. 1993a), whereas the half-life of 5aR-2 mRNA is unknown. As for $5 \alpha \mathrm{R}-1$, further studies are required to measure 5 $\alpha \mathrm{R}-2$ mRNA and activity over several timepoints. Additional studies are also required to determine the effect of other hormones on the regulation of the $5 \alpha \mathrm{R}$ isoforms. For example, in genital skin fibroblasts, which exclusively express the $5 \alpha \mathrm{R}-2$ isoform, $5 \alpha \mathrm{R}-2$ activity has been shown to be regulated by DHT and insulin-like growth factor-I (Horton et al. 1993), transforming growth factor- $\beta 1$ and $-\beta 2$ (Wahe et al. 1993) and activin A (Antonipillai et al. 1995).

As mentioned above, $5 \alpha \mathrm{R}-2$ enzyme activity decreased when FSH. $A b$ was co-administered with hCG. Surprisingly, co-administration of FSH. $A b$ with hCG increased $5 \alpha \mathrm{R}-2$ at the mRNA level. However, in the TE suppression model, FSH. $A b$ administration decreased $5 \alpha \mathrm{R}-2$ mRNA. The discrepancy between these findings is unexplained but it is possible that the increase in $5 \alpha \mathrm{R}-2$ mRNA after FSH suppression in hCG-treated animals is partly due to the presence of testosterone in these animals. A difference between these in vivo models is that GnRH immunisation produces more severe spermatogenic regression and FSH is chronically suppressed in GnRH-immunised animals, whereas FSH is only acutely suppressed in the TE-suppression model.

$5 \alpha \mathrm{R}$ isoform mRNA and activity were expressed on a per gram of testis basis in order to investigate the testicular concentrations of these enzymes, and their relationship to the testicular androgen concentration. The significant changes in $5 \alpha \mathrm{R}-1$ and $5 \alpha \mathrm{R}-2$ induced by hormonal treatment of TE-treated or GnRH-immunised rats, in the absence of changes in testis weight, may be a consequence of modulation of the regulation and expression of these enzymes in Leydig and Sertoli cells, both of which have been demonstrated to contain at least $5 \alpha \mathrm{R}-1$ (Dorrington \& Fritz 1975, Nayfey et al. 1975, Welsh \& Wiebe 1976, Murono \& Payne 1979, Viger \& Robaire 1995). Since restoration of testosterone and/or FSH in these models cause increases in some germ cell populations (Meachem et al. 1998), it is also possible that the changes in the testicular concentration of $5 \alpha \mathrm{R}$ isoforms is related to the appearance of certain germ cell types. Although it seems that $5 \alpha \mathrm{R}-1$ is present predominantly in Leydig cells (Viger $\&$ Robaire 1995) there is also evidence for $5 \alpha \mathrm{R}$ activity (probably $5 \alpha \mathrm{R}-1$ ) in seminiferous tubules, in Sertoli cells as well as germ cells (Dorrington \& Fritz 1975). The localisation of $5 \alpha \mathrm{R}-2$ in the testis is unknown.

Interpretation of changes in the concentration of $5 \alpha \mathrm{R}$ isoforms between untreated controls and treated (TEtreated or GnRH-immunised) animals is complicated by the fact that there are large changes in testis weight induced by these treatments. These differences in testis weight are related to the disappearance of various germ cells from the testis (Meachem et al. 1998) and are not likely to be related to changes in Sertoli cell numbers (McLachlan et al. 1995). The data expressed per gram of testis show that TE-treated and GnRH-immunised animals have an increase in the concentration of $5 \alpha \mathrm{R}-1$ activity; however, if the data were expressed on a per testis basis no changes would be seen. Nevertheless, analysis of the testicular androgen levels showed that the ability of the testis to produce $5 \alpha$-reduced androgens is increased when the testis is in a hypogonadotrophic state. This is demonstrated by an increase in the amount of DHT and 3 $\alpha$-Adiol produced when taking into account the large decrease in substrate (testosterone) concentration. Thus, TE treatment or GnRH immunisation increased the capacity of the testis to produce $5 \alpha$-reduced androgens. This increased capacity correlated with an increase in the testicular concentration of $5 \alpha \mathrm{R}-1$ activity, suggesting that the concentration of this enzyme in particular is important for the production of $5 \alpha$-reduced androgens in the testis.

Thus, this study showed that the concentration of $5 \alpha$-reduced metabolites in the testis is influenced by expression of $5 \alpha \mathrm{R}-1$ rather than $5 \alpha \mathrm{R}-2$, and that the $5 \alpha \mathrm{R}-1$ isoform appears to be negatively regulated by testosterone. Thus $5 \alpha \mathrm{R}-1$, which is the predominant $5 \alpha \mathrm{R}$ isoform in rat testis (Pratis et al. 2000), is important for testicular $5 \alpha$-reduced androgen biosynthesis. We have shown previously in rats that synthesis of $5 \alpha$-reduced androgens in the testis is particularly important for the maintenance of androgenic effects on spermatogenesis when testicular testosterone levels are experimentally lowered in a model of contraception (O'Donnell et al. 1996, 1999). The results presented here extend the previous studies to suggest that when testicular testosterone levels are low, the concentration of $5 \alpha \mathrm{R}-1$ in the testis is increased, thereby allowing increased production of the more potent androgen DHT, and hence amplification of the androgenic stimulus on spermatogenesis. In terms of relevance to clinical contraceptive studies, the maintenance of testicular $5 \alpha$-reduced androgen levels during testosterone-based contraception has been suggested to be associated with the continued low level of sperm production in oligospermic responders (Anderson et al. 1996, 1997). Therefore we speculate that increases in testicular $5 \alpha \mathrm{R}-1$ activity in the human testis may occur during contraceptive treatment, as a consequence of the negative regulation of $5 \alpha \mathrm{R}-1$ expression by testosterone, and may underlie the maintenance of spermatogenesis in oligospermic men. Further studies are required to assess $5 \alpha \mathrm{R}-1$ expression and activity in the human testis. Considering that $5 \alpha \mathrm{R}-1$ appears to be the predominant $5 \alpha \mathrm{R}$ expressed in human testis (Aumuller et al. 1996) and that administration of specific $5 \alpha \mathrm{R}-2$ inhibitors failed to induce complete suppression of spermatogenesis in men undergoing hormonal contraception (McLachlan et al. 2000, Kinniburgh et al. 2001), it is possible that selective inhibition of $5 \alpha \mathrm{R}-1$ or dual inhibition of both $5 \alpha \mathrm{R}$ 
isoforms may be warranted to improve the degree of spermatogenic suppression during testosterone-based contraceptive administration. In addition, our studies show that FSH can influence $5 \alpha \mathrm{R}-1$ and $5 \alpha \mathrm{R}-2$, suggesting that circulating levels of FSH could also modulate $5 \alpha$-reduced androgen biosynthesis in the testis. In summary, this study suggests that the concentrations of testicular $5 \alpha \mathrm{R}$ isoforms are hormonally regulated, and highlights the contribution of the $5 \alpha \mathrm{R}-1$ isoform to $5 \alpha$-reduced androgen biosynthesis.

\section{Acknowledgements}

This study was supported by the National Health and Medical Research Council of Australia Program Grant (No. 983212). L O'D received support from the Wellcome Trust Research Training Fellowship in Reproductive Biology (No. 050387). We would like to thank Fiona McLean for the analysis of testicular steroids.

\section{References}

Anderson RA, Wallace AM \& Wu FCW 1996 Comparison between testosterone enanthate-induced azoospermia in a male contraceptive study. III. Higher $5 \alpha$-reductase activity in oligozoospermic men administered supraphysiological doses of testosterone. Journal of Clinical Endocrinology and Metabolism 81 902-908.

Anderson RA, Kelly RW \& Wu FCW 1997 Comparison between testosterone enanthate-induced azoospermia and oligozoospermia in a male contraceptive study. V. Localization of higher $5 \alpha$-reductase activity to the reproductive tract in oligozoospermic men administered supraphysiological doses of testosterone. Journal of Andrology 18 366-371.

Andersson S \& Russell DW 1990 Structural and biochemical properties of cloned and expressed human and rat steroid 5a-reductases. PNAS 87 3640-3644.

Antonipillai I, Wahe M, Yamamoto J \& Horton R 1995 Activin and inhibin have opposite effects on steroid $5 \alpha$-reductase activity in genital skin fibroblasts. Molecular and Cellular Endocrinology 107 99-104.

Aumuller G, Eichler W, Renneberg H, Adermann K, Vilja P \& Forssmann WG 1996 Immunocytochemical evidence for differential subcellular localization of $5 \alpha$-reductase isoenzymes in human testis. Acta Anatomica 156 241-252.

Awoniyi CA, Santulli R, Sprando RL, Ewing LL \& Zirkin BR 1989 Restoration of advanced spermatogenic cells in the experimentally regressed rat testis: quantitative relationships to testosterone concentrations within the testis. Endocinology 124 1217-1223.

Bhasin S, Fielder TJ \& Swerdloff RS 1987 Testosterone selectively increases serum follicle-stimulating hormone (FSH) but not luteinizing hormone $(\mathrm{LH})$ in gonadotrophin-releasing hormone antagonist-treated male rats: evidence for differential regulation of LH and FSH secretion. Biology of Reproduction 37 55-59.

Bustin SA 2000 Review: absolute quantification of mRNA using real-time reverse transcription polymerase chain reaction assays. Journal of Molecular Endocrinology 25 169-193.

Dorrington JH \& Fritz IB 1975 Cellular localization of $5 \alpha$-reductase and $3 \alpha$-hydroxysteroid dehydrogenase in the seminiferous tubule of the rat testis. Endocrinology 96 879-889.
Haavisto A-M, Pettersson K, Bergendahl M, Perheentupa A, Roser JF \& Huhtaniemi I 1993 A supersensitive immunofluorometric assay for rat luteinising hormone. Endocrinology 132 1687-1691.

Horton R, Pasupuletti V \& Antonipillai I 1993 Androgen induction of steroid $5 \alpha$-reductase may be mediated via insulin-like growth factor-I. Endocrinology 133 447-451.

Jenkins EP, Andersson S, Imperato-McGinley J, Wilson JD \& Russell DW 1992 Genetic and pharmacological evidence for more than one human steroid $5 \alpha$-reductase. Journal of Clinical Investigation $\mathbf{8 9}$ 293-300.

Kinniburgh D, Anderson RA \& Baird DT 2001 Suppression of spermatogenesis with desogestrel and testosterone pellets is not enhanced by addition of finasteride. Journal of Andrology 22 88-95.

Lephart ED, Simpson ER \& Trzeciak WH 1991 Rat adrenal $5 \alpha$-reductase mRNA content and enzyme activity are sex hormone dependent. Journal of Molecular Endocrinology 6 163-170.

Lopez-Solache I, Luu-The V, Seralini GE \& Labrie F 1996 Heterogeneity of rat type $15 \alpha$-reductase cDNA: cloning, expression and regulation by pituitary implants and dihydrotestosterone. Biochimica et Biophysica Acta 1305 139-144.

Marcantonio D, Chalifour LE, Alaoui-Jamali MA \& Huynh HT 2001 SSGI is an androgen regulated gene expressed in prostatic smooth muscle cells in vivo. Journal of Molecular Endocrinology 26 175-184.

McLachlan RI, Wreford NG, Tsonis C, de Kretser DM \& Robertson DM 1994 Testosterone effects on spermatogenesis in the gonadotrophin-releasing hormone-immunized rat. Biology of Reproduction 50 271-280.

McLachlan RI, Wreford NG, de Kretser DM \& Robertson DM 1995 The effects of recombinant follicle-stimulating hormone on the restoration of spermatogenesis in the gonadotropin-releasing hormone-immunized adult rat. Endocrinology 136 4035-4043.

McLachlan RI, McDonald J, Rushford D, Robertson DM, Gerrett C \& Baker G 2000 Efficacy and acceptability of testosterone implants, alone or in combination with a $5 \alpha$-reductase inhibitor, for male hormonal contraception. Contraception 62 73-78.

McLachlan RI, O’Donnell L, Stanton PG, Balourdos G, Fryenberg M, de Kretser DM \& Robertson DM 2002 Effects of testosterone plus medroxyprogesterone acetate on semen quality, reproductive hormones and germ cell populations in normal young men. Journal of Clinical Endocrinology and Metabolism 87 546-556.

Meachem SJ, Wreford NG, Stanton PG, Robertson DM \& McLachlan RI 1998 Follicle-stimulating hormone is required for the initial phase of spermatogenic restoration in adult rats following gonadotropin suppression. Journal of Andrology 19 725-735.

Murono EP \& Payne AH 1979 Testicular maturation in the rat. In vivo effect of gonadotropins on steroidogenic enzymes in the hypophysectomized immature rat. Biology of Reproduction 20 911-917.

Narula A, Gu YQ, O'Donnell L, Stanton PG, Robertson DM, McLachlan RI \& Bremner WJ 2002 Variability in sperm suppression during testosterone administration to adult monkeys is related to follicle stimulating hormone suppression and not to intratesticular androgens. Journal of Clinical Endocrinology and Metabolism 87 3399-3406.

Nayfey SN, Coffey JC, Hansson V \& French FS 1975 Maturational changes in testicular steroidogenesis: hormonal regulation of 5 $\alpha$-reductase. Journal of Steroid Biochemistry 6 329-335.

Normington K \& Russell DW 1992 Tissue distribution and kinetic characteristics of rat steroid $5 \alpha$-reductase isozymes. Journal of Biological Chemistry 267 19548-19554.

O’Donnell L, Stanton PG, Wreford NG, Robertson DM \& McLachlan RI 1996 Inhibition of $5 \alpha$-reductase activity impairs the testosterone-dependent restoration of spermiogenesis in adult rats. Endocrinology 137 2703-2710.

O’Donnell L, Pratis K, Stanton PG, Robertson DM \& McLachlan RI 1999 Testosterone-dependent restoration of spermatogenesis in adult rats is impaired by a $5 \alpha$-reductase inhibitor. Journal of Andrology $\mathbf{2 0}$ 109-117. 
Pratis K, O'Donnell L, Ooi GT, McLachlan RI \& Robertson DM 2000 Enzyme assay for $5 \alpha$-reductase type 2 activity in the presence of $5 \alpha$-reductase type 1 activity in rat testis. Journal of Steroid Biochemistry and Molecular Biology 75 75-82.

Rea MA, Marshall GR, Weinbaurer GF \& Nieschlag E 1986 Testosterone maintains pituitary and serum FSH and spermatogenesis in gonadotropin-releasing hormone antagonist-suppressed rats. Journal of Endocrinology 109 101-107.

Rivarola MA, Podesta EJ \& Chemes HE 1972 In vitro testosterone- $-{ }^{14} \mathrm{C}$ metabolism by rat seminiferous tubules at different stages of development: formation of $5 \alpha$-androstandiol at meiosis. Endocrinology 91 537-542.

Stewart A, Valentine J, Tsonis C, Borchers C, Russell-Jone G, Headon D, Worral M, Clifton G, McInerney B \& Forage R 1992 Immunisation using recombinant TraT-LHRH fusion proteins. In Vaccines, vol 92, pp 51-55. Eds F Brown, RM Chaneck, H Ginsberg \& RE Lerner. Cold Spring Harbor, NY: Cold Spring Harbor Laboratory.

Thigpen AE, Cala KM \& Russell DW 1993a Characterization of Chinese hamster ovary cell lines expressing human steroid $5 \alpha$-reductase isozymes. Journal of Biological Chemistry 268 17404-17412.

Thigpen AE, Silver RI, Guileyardo JM, Casey ML, McConnell JD \& Russell DW $1993 b$ Tissue distribution and ontogeny of steroid $5 \alpha$-reductase isozyme expression. Journal of Clinical Investigation 92 903-910.
Viger RS \& Robaire B 1995 Steady state steroid 5 $\alpha$-reductase messenger ribonucleic acid levels and immunocytochemical localization of the type 1 protein in the rat testis during postnatal development. Endocrinology 136 5409-5415.

Wahe M, Antonipillai I \& Horton R 1993 Effects of transforming growth factor $\beta$ and epidermal growth factor on steroid $5 \alpha$-reductase activity in genital skin fibroblasts. Molecular and Cellular Endocrinology 98 55-59.

Welsh MJ \& Wiebe JP 1976 Sertoli cells from immature rats: in vitro stimulation of steroid metabolism by FSH. Biochemical and Biophysical Research Communications 69 936-941.

Wright WW \& Frankel AI 1979 Endogenous androgen concentrations in nuclei isolated from seminiferous tubules of mature rat testis. Journal of Steroid Biochemistry 10 633-640.

Yates EF, Herbst AL \& Urquhart J 1958 Sex differences in rate of ring A reduction of $\Delta^{4}-3$-keto-steroids in vitro by rat liver. Endocrinology 63 887-902.

Yeap BB, Krueger RG \& Leedman PJ 1999 Differential posttranscriptional regulation of androgen receptor gene expression by androgen in prostate and breast cancer cells. Endocrinology 140 3282-3291.

Received 26 September 2002

Accepted 26 November 2002 